Jasmina Bogićević1

Violeta Domanović ${ }^{2}$

University of Kragujevac,

Faculty of Economics

Bojan Krstić ${ }^{3}$

University of Niš,

Faculty of Economics
ORIGINAL SCIENTIFIC ARTICLE doi:10.5937/ekonomika1603001B

Received: Jun 28, 2016 Accepted: August 23, 2016

\title{
THE ROLE OF FINANCIAL AND NON-FINANCIAL PERFORMANCE INDICATORS IN ENTERPRISE SUSTAINABILITY EVALUATION
}

\begin{abstract}
Valid analysis and assessment of the sustainability of the company are based on adequate and reliable information spectrum. Therefore, emphasis should be placed on the selection criteria for assessing the sustainability. In this context, it must be decided whether the assessment of the sustainability should be based solely on financial reporting figures that reflect its financial position or it is necessary to use other parameters. For this reason, in recent years it is highlighted the necessity of an integrated reporting model for assessing the sustainability. Such an approach means taking into account not only financial criteria but also criteria that reflect both internal and external environment. The purpose of the research is to highlight the role of integrated information spectrum for the purposes of assessing the sustainability. In this regard, the paper analyzes the different models for assessing the sustainability in the EU and is considering the possibility of their use in enterprises in the Republic of Serbia.
\end{abstract}

Key words: integrated reporting model, sustainability, financial measures and non-financial measures.

JEL classification: M21, M41.

\section{УЛОГА ФИНАНСИЈСКИХ И НЕФИНАНСИЈСКИХ ИНДИКАТОРА ПЕРФОРМАНСИ У ОЦЕНИ ОДРЖИВОСТИ ПРЕДУЗЕһА}

\footnotetext{
Апстракт

Валидна анализа и оцена одрживости предузећа се заснивају на адекватном и поузданом информационом спектру. Стога, акценат треба ставити на избор мерила за оцену одрживости предузећа. У том контексту, треба

1 jasminabogic@ptt.rs.

2 violeta.domanovic@gmail.com

3 bojan.krstic@eknfak.ni.ac.rs
} 
донети одлуку да ли оцену одрживости предузећа засновати искључиво на финансијско-извештајним бројкама које рефлектују његов финансијски и приносни положај или је неопходно да се за те потребе користе и други параметри. Из тог разлога се у последюе време истиче неопходност примене интегралног модела извештавања за очену одрживости предузећа. Такав приступ оцени одрживости предузећа подразумева узимање у обзир не само финансијских мерила, већ и мерила која одражавају како интерно, тако и екстерно окружење. Сврха истраживања је истицање улоге интегралног информационог спектра за потребе очене одрживости предузећа. С тим у вези, у раду се анализирају различити модели за оцену одрживости предузећа у Европској унији и разматра могућност юихове примене у предузећима у Републици Србији.

Кључне речи: модел интегрисаног извештавања, одрживост предузећа, финансијска мерила и нефинансијска мерила.

\section{Introduction}

Conventional accounting model, especially its financial reporting segment, cannot provide adequate answers to numerous questions coming from various stakeholders. Traditional accounting framework does not fully meet the requirements of managers, investors, and creditors for identifying and monitoring the company performance. Therefore, academic and professional communities point to the need for basing the evaluation of company performance not only on financial, but also on non-financial information.

Davis and Albright (2004) argue that the application of performance measurement system is often recommended in order to improve strategy implementation and to increase organizational performance. Contemporary performance measurement models imply the use of both financial and non-financial criteria in line with the business strategy (Krstić \& Sekulić, 2013). Balanced scorecards (BSC) and multi-criteria key performance indicators (KPI) are usually distinguished as examples of contemporary models (Krstić, 2012). The adoption of such systems has been growing steadily over the last two decades. Companies are increasingly under pressure to deliver value not only to shareholders, but also to other stakeholders, and are increasingly convinced that contemporary performance measurement models can be of help in the realization of this task (Ittner et al., 2003). Researchers in this field are aware why companies adopt these systems.

The research subject is company performance evaluation, with special emphasis on evaluating the performance of companies in the European Union and the Republic of Serbia. The aim of the research is to gain insight into the prevalence of different models and criteria for evaluating the company performance in the European Union and the Republic of Serbia. The starting hypothesis is that companies in the European Union use contemporary integrated models for evaluating the company performance, unlike companies in Serbia, which still base company performance evaluation on traditional 
financial measures. In order to test the starting hypothesis, qualitative methodology will be used, based on the study and a descriptive analysis of the research problem, while, based on empirical studies by various authors in the field of accounting and business economics and management, the aggregation of different positions will be carried out, through the method of synthesis and deduction. For comparative analysis of models for evaluating the company performance in the European Union and the Republic of Serbia, comparative research method is applied.

Starting from the defined subject, aim, and the starting hypothesis, the paper will first point out the possibilities and limitations of financial performance measures; then, the focus will be on the role of integrated reporting model in the evaluation of company performance; the following part will deal with the implementation of integrated reporting model in the process of evaluation of company performance in the European Union, whereas the final part will analyze the implementation of various performance measures in companies in the Republic of Serbia.

\section{Financial performance indicators for sustainability evaluation}

Accounting plays a key role in evaluating the company performance primarily through the preparation and presentation of a set of financial statements. As a kind of reporter and editor of the business life of companies, accounting aims at using these final products to provide information to the right users, in the right quantity (multum non multa), in a timely manner, in an appropriate form, and at an acceptable cost. Since financial statements give both quantitative and qualitative data, authors often emphasize their completeness (Kothari \& Barone, 2006). However, financial statements can serve "not only as a map, but a maze" to their users (Fraser \& Ormiston, 2013). As a map, financial statements are an adequate basis for understanding the financial position of a company and for evaluating its past and expected success. Therefore, it is no wonder that primacy within the first module of Sustainability Evaluation and Reporting System (SERS) belongs to information in the statement of financial position (balance sheet), income statement, and cash flow statement. The significance of these navigational accounting instruments is reflected in the fact that the analytical interpretation of the data contained therein enables the identification and monitoring of key financial performance indicators of the company.

The relevant literature in the field of business economics, management, and accounting provides no single definition of the syntagm "financial performance". There being no generally accepted definition, different views of this important aspect of the general economic position of the company have appeared in theory and practice, which can be systematized into two groups, namely:

a. Financial performance in the narrow sense and

b. Financial performance in a broader sense.

According to a narrow concept, evaluation of financial performance of the company is based solely on parameters that directly reflect the company results. Accordingly, evaluation of performance in the narrow sense relies solely on profitability indicators. This belief is held by Peterson-Drake and Fabozzi (12), who use return on investment 
(ROI) as the most representative indicator of financial performance. Depending on the type of investment, these authors alternatively observe this measure of performance. In this regard, they point out that summary of ROI includes rate of return on assets (ROA) and return on equity (ROE). Narrow understanding of financial performance is also held by Fraser and Ormiston (2013), who, as the key criteria of profitability, in addition to the above, point to the rate of operating income and rate of net income. Pointing out that financial performance measures are indicators identified on the basis of accounting data, Doupnik and Perera (2007) suggest the following criteria: growth in operating income, cost reduction, profit, and return on investment. As the primary advantage of profit, as the most relevant performance measure, these authors point out that profit numerically summarizes activities of all business functions. Therefore, it is no wonder that the most common measures of financial performance in the narrow sense are based on profit. In this regard, Earnings before Interest and Taxes (EBIT) and Earnings before Interest, Taxes, Depreciation, and Amortization (EBITDA) have started being used as parameters.

According to a broader understanding of financial performance, evaluation of this complex category should rely on criteria determined on the basis of information contained in financial statements, as well as other relevant accounting information. In this context, when evaluating financial performance, the majority of authors use not only various profitability indicators, but also indicators of liquidity, solvency, and activity. Some of the proponents of broader understanding of financial performance are Cotter (2012), Davies and Pain (2002), White, Sondhi, and Fried (1993). Moreover, some authors see market share (Chen et al., 2009) as financial performance indicators, which de facto stand for indicators of growth and competitiveness (Kotane \& Kuzmina-Merlino).

On the whole, regardless of whether financial performance is treated in the narrow or broad sense, the main sources used for its evaluation are provided by data in the statement of financial position, income statement, and cash flow statement. In fact, even the authors who advocate a narrower concept of financial performance take information from both income statement and statement of financial position for the assessment of global profitability indicators. In other words, they believe that information about profitability flow gains in importance only when brought in line with the engaged resources. Proponents of a broader concept of financial performance in particular point to the fact that, in the process of evaluation, basic financial statements cannot be treated as alternative, but as complementary information sources. Pointing to the unbreakable bonds between statement of financial position and income statement, they rightly state that financial performance indicators (partial indicators of profitability), determined solely on the basis of income statement, are per se irrelevant if not accompanied by indicators identified on the basis of balance sheet and cash flow statement (indicators of liquidity, solvency, and partly activity). Even the analysis of liquidity, based on data in the balance sheet, can only provide certain incomplete signs of actual liquidity, which is why this analytical approach is used only as an initial provisional process of meticulous analysis. Therefore, static liquidity ratios are often supplemented by the analysis of cash flows that represent the company bloodstream, and cash flows from operations are qualified as the key performance measure (Grant, 2002). In this context, operating cash flow liquidity ratio is a particularly important indicator of financial performance.

Cash flows from operating activities can be a critical measure of business success. As pointed out by Fraser and Ormiston (2013), "the amount of net income in the income 
statement is ultimately irrelevant if the company is unable to translate its gains into cash". Cash flows generated during the accounting period are facts, not dependent on evaluation or use of alternative accounting conventions and valuation methods. In other words, all cash flow statement items are based on money and are easy to measure. Emphasizing the comparative advantages of this financial statement, Davies and Pain (2002) point out that "unacceptable degree of subjectivity that comes to the fore in the preparation of income statement, thus in some way discrediting this statement, contributes to the popularity of the cash flow statement".

Despite the indisputable possibilities offered by financial criteria, it is necessary to point out their deficiencies and incompleteness for the purposes of evaluating the company performance. First of all, the financial statements are a retrospective reflection of the business and financial life of the company on a particular day or over a particular period, and, as such, allow for the identification of historically oriented financial performance measures of the company. As already stated, beside map, financial statements may be a maze that brings into question how to understand ability of their content. Therefore, plenty of information contained in the financial statements "may seem confusing and disorienting" (Davis \& Albright, 2004), thus bringing into question the reliability of its use. The complexities of accounting rules, which are often subject to change, as well as the managers' discretion to numerically design financial statements, represent the kind of problem when evaluating the company performance. Moreover, according to Fraser and Ormiston (2013), "some of the key information needed for evaluating the company performance is not available in financial statements, some is hard to find, and many is impossible to measure". Therefore, it is no wonder that in recent years focus has been on the necessity of using non-financial criteria for the purposes of evaluating the company performance.

\section{The use of integrated reporting in sustainability evaluation}

Lately, there have been more and more indications of the mismatch of content found in financial statements of companies and information required by their key stakeholders for the purpose of evaluating performance. In fact, the focus has been on the fact that evaluation of company performance should be based on a holistic, i.e. integrated approach, which involves the simultaneous use of financial and non-financial measures. It is this integrated reporting paradigm that fully reflects the context in which the company operates (Krstić \& Bonić, 2013).

The ultimate goal of the company can be easily qualified as the value creation (Jensen, 2001; Grant, 2002). In order to reach the stated goal, companies should not ignore the context within which they realize their activities. The prevailing view in literature is that this context should be seen as a network of relations between the company and a large number of its stakeholders. In other words, relations between the company and its key stakeholders determine its potential for sustained and continuous operations (Perrini $\&$ Tencati, 206). Given that a complete set of relationships with stakeholders has strategic importance for the long-term success and survival of the company, Perrini and Tencati (2006) claim that measuring the success of a corporation should not be limited solely to value creation for one interest group, i.e. shareholders. Taking into account the needs of 
other stakeholders (employees, clients, suppliers, financial partners, government, local community, and society in general) in evaluating the company performance results in the adoption of a holistic and integrated framework. It is an extremely flexible framework that extends and enhances traditional financial and economic approaches to performance measurement, which is modelled primarily in accordance with the needs and demands of stakeholders.

Although the idea of redesigning the performance evaluation framework appeared in the United States at the end of the twentieth century, it is still supported by outstanding international and European institutions. These institutions have also contributed to the development of an integrated reporting model and the definition of key performance indicators. Among them, special importance belongs to a non-profit organization, Global Reporting Initiative (GRI), which has created a reporting framework and a set of indicators that relate to the issues of environmental protection, society, and economy. It is believed that Sustainability Reporting Guidelines developed by GRI are the most common non-financial reporting framework used in practice. Furthermore, GRI has already four times updated Sustainability Reporting Guidelines. According to the latest version (G4), the framework provides guidance to all world organizations, regardless of their size, in relation to the reporting forms, fields that should be disclosed and key performance indicators. It is, therefore, no wonder that this integrated reporting framework is widely used around the world. Although GRI's intention was to make these guidelines facilitate the standardization of company reporting process, they are sometimes differently interpreted and applied in practice. United Nations Conference of Trade and Development (UNCTAD) contributed to the affirmation of non-financial performance indicators when it adopted the 2008 Corporate Responsibility Guidelines, stating indicators on the protection of the environment, society, and corporate governance. A similar set of non-financial criteria was in the same period suggested by the Chartered Financial Analyst Institute (CFA Institute) and the European Federation of Financial Analyst Societies (EFFAS). In addition to these institutions, strong contribution to the affirmation of non-financial performance measures was given by the International Federation of Accountants (IFAC) in 2011, which insisted that the key performance measures are those relating to the protection of the environment, society, and governance. On 29 September 2014, Council of the European Union adopted a new Directive 2014/95/ EU relating to the disclosure of non-financial and variety of information at the level of large companies and groups. The Directive entered into force on 6 December 2014, and represents a kind of supplement to the Directive 2013/34/EU, which refers to the annual individual and consolidated financial statements.

An important role in the development of efficient and effective methodology for comprehensive evaluation of the company sustainability has been given to the academic community. An illustrative example of this contribution can be Sustainability Evaluation and Reporting System (SERS), derived from theoretical analyses and empirical research conducted by Italian authors Perrini and Tencati (2006). This system includes the following three modules: (1) integrated reporting system, (2) integrated information system, and (3) key performance indicators of company sustainability (Perrini \& Tencati, 2006). In contrast to the second and the third model, which are one-dimensionally presented, the first module, called an integrated reporting system, includes: annual report, social report, environmental report, and a set of integrated performance indicators. As the annual 
report was already considered in the context of financial performance, the following part will discuss the social report and the environmental report.

The focus of the social dimension of corporate sustainability is on the impact of the organization on social systems within which it operates (Krstić \& Ivanović, 2014). Social report contains information on the impact of the company and its activities on various interest groups. In the selection of social performance indicators, it is necessary to determine the standards or guidelines dealing with social issues. Social issues are at the core of modern concepts of Corporate Social Responsibility (CSR), Social Accountability 8000, and Socially Responsible Investing. Social report allows management decision-making and corporate communications. It includes ethics policy, a report on the added value, and analysis of relationships between stakeholders. Social performance is focused on working practices, human rights, and broader social issues that tackle a wide range of stakeholders (Hřebíček et al., 2012). The second part of the social report is a report on the added value, which is the traditional instrument of social reporting and also the link between traditional financial accounting and social reporting. It measures the financially expressed value added that the company creates and distributes to a variety of stakeholders. Analysis of the relationship between interest groups on the basis of qualitative and quantitative information is intended to evaluate the sustainability of the company interaction with its constituents (Krstić et al., 2012).

Environmental indicators relate to the impact which the organization, through its products, services, and activities, exerts on the environment (Krstić et al., 2013). The company uses environmental indicators to control activities and to communicate with stakeholders that are particularly interested in environmental issues. Although there is no single model of this report, this reporting segment of SERS should contain two important flows of information: flow relating to physical data - accounting of energy and materials and flow relating to financial items - monetary environmental accounting. While accounting of energy and materials collects information on the impact of company activities on the environment, monetary accounting determines the costs and benefits arising from the environmental management of products and processes (Perrini \& Tencati, 2006). A relevant segment of the first SERS module represents a set of integrated performance indicators associating physical and technical quantities with financial values, thus providing a number of user groups with complete insight into corporate activities and behaviour. An integrated information system is the core of the process of evaluation and reporting on the company performance (Perrini \& Tencati, 2006). Based on modern information and communication technology achievements, this module allows the collection, processing, and distribution of physical/technical and financial data. It is this element that represents the starting level for the introduction of the accounting systems pertaining to the environment and society in order to integrate and improve the existing methodologies of financial accounting and cost accounting. Finally, the last module, called Key Performance Indicators, is a crucial element of SERS methodology (Perrini \& Tencati, 2006). Due to lack of time and resources, small and medium-sized enterprises are unable to determine the complicated system of reporting on sustainability. Since they also need a map for continuous evaluation of performance and quality of relations with stakeholders, this group of companies uses key performance indicators as a sort of roadmap for these purposes.

It is evident that the previously discussed SERS methodology enables the company to manage relationships with stakeholders, to respond to their information requests, and to deal with economic, social, and environmental issues. 


\section{Comparative analysis of the evaluation of company performance in the countries of the European Union and the Republic of Serbia}

In the European Union countries, the annual report consists of financial statements and voluntary notes, as well as a document that is referred to as management commentary or management discussion and analysis, containing specific non-financial information related to a particular company. Bini and Danielli (2011) discuss the role of the European Directive 2003/51, which requires managers to present a set of ratios to highlight the financial performance, namely return on equity (ROE), return on investment (ROI), and return on sales (ROS). The authors analyze the report in four European Union countries (Germany, Italy, United Kingdom, and the Netherlands), respecting differences in cultural, economic, financial, and regulatory environment. They propose an integrated approach to the analysis and evaluation of the quality of the presentation of financial and non-financial information. They point out the results of research on the relationship between voluntary disclosure of financial ratios and corporate characteristics in the period 1989-1993, based on a sample of 313 large companies in the United Kingdom. Their focus is on investment ratios, debt ratios, and profitability ratios as the financial criteria. They point out that financial ratios vary from company to company and that the nature of the industry, company performance, and size are factors that influence the policy of disclosure of financial ratios. Black Sun compared the disclosure practice of 100 companies in 2005 and 2006, and concluded that $79 \%$ of reports in 2006 contained financial key performance indicators (FKPI), compared to 2005 when 56\% of such reports were recorded (Bini \& Danielli, 2011). Deloitte conducted an annual survey on a sample of 130 companies whose shares are quoted on the London Stock Exchange. The study showed an increase in the number of financial key performance indicators from four to five between 2008 and 2009 (Bini \& Danielli, 2011). Similar situation was with companies in Italy. The Scandinavian countries disclose more financial indicators than companies in the United Kingdom.

According to German Accounting Standards (GAS) of January 2010, the managers' report should contain the following parts (Bini \& Danielli, 2011): description of the business environment, information about the profits, financial position of the company, assets and liabilities, report on events after the balance sheet date, report on the risk, as well the report on the expected growth. Out of financial criteria, according to the above-mentioned standards, net income, return on assets, leverage, profitability, market ratios, debt ratios, and liquidity ratios are applied. Out of non-financial criteria, environmental indicators and indicators that apply to employees are applied (water and energy consumption, carbon emissions, employee training, and employee participation in the distribution of profits, etc.), as well as indicators relating to customers.

In the United Kingdom, companies must prepare the Strategic Report. Strategic Report must include, among other things, description of the main risks and uncertainties which the company is facing, and analysis of relevant environmental issues and issues relating to employees on the basis of key performance indicators. In addition, Strategic Report must include information on environmental policy, employee issues, social issues, community issues, and human rights. The new Directive introduces the obligation for companies to publish the results of existing anti-corruption policies and results. In the United Kingdom, Strategic Report should contain information that is beneficial to 
shareholders. The main purpose of the Report is to provide information to shareholders so that they could evaluate the directors' performance in the process of realization of company success, and to evaluate their achievements and anticipate the same in the future.

Member countries of the European Union, such as Austria, Belgium, Denmark, Finland, Germany, the Netherlands, and Sweden, formally refer to the Global Reporting Initiative in their documents or policies. In Sweden, for example, state-owned enterprises must prepare a sustainability report in accordance with the guidelines of the Global Reporting Initiative. The EU member states have two years to incorporate the Directive 2014/95/EU into their national legislation. In this regard, the European Commission organizes informal workshops on this topic in order to help governments of individual countries. The first workshop of that kind was held in Brussels on 24 March 2015. It turned out to be a useful forum for the exchange of experience among the EU member states and discussion of practical implementation issues. A large number of EU member states have already begun the process of incorporation of the Directive into their legislation, and have specific implementation plans, while some countries are already at an advanced stage.

Perrini and Tencati (2006) point out that the balanced scorecard model, GRI Sustainability Reporting Guidelines, and Sustainability Integrated Guidelines for Management are not entirely suitable for small and medium-sized enterprises due to their complexity, limited flexibility, and formal procedures. The authors introduce an efficient and effective methodology for an integrated evaluation of company sustainability in order to support new reporting models (with a special focus on small and medium-sized enterprises), with the purpose of integration of financial and non-financial performance measures, improving the quality of decision-making processes and management, and strengthening corporate accountability and responsiveness to various stakeholders.

Kotane and Kuzmina-Merlino (2012) point out that companies in Latvia apply current liquidity ratio, debt-to-equity ratio, gross profit, return on assets (ROA), and return on equity (ROE) in the process of financial analysis.

Significant dimension of company performance evaluation is the evaluation of corporate social responsibility (CSR). The corporate social responsibility index measures the corporate social responsibility practices in the broadest sense, includes reporting on sustainability, and measures various activities and processes in the field of corporate social responsibility. Gjølberg (2008) points out those Nordic companies are generally subject to strict social and environmental regulations, and that they are very dedicated to the international agenda on corporate social responsibility. British and Dutch civil societies are actively involved in corporate social responsibility, with organizations such as SustainAbility, AccountAbillity, and the GRI secretariat, which contribute to increased corporate social responsibility efforts in their communities. Positive results from Spain and France in this domain are surprising. Companies from these countries are not considered very active in the global community of corporate social responsibility. This conclusion is derived on the basis of Initial corporate social responsibility index, which includes the participation of organizations in the CSR community (Global Compact) and the practice of reporting on corporate social responsibility (Global Reporting Initiative $G R I)$. Based on all other indicators, France and Spain have low or negative points. This could indicate that the Spanish and French business communities have taken an active 
role in corporate social responsibility, but so far have failed to achieve sufficient results to qualify for more demanding initiatives. It will be remarkable to see whether efforts of French and Spanish companies will bring performance improvement in the future.

On the other hand, a negative result of Germany is puzzling, given the fact that Germany is known for its high environmental standards. Possible explanation lies in the fact that Germany is a big economy of great regional importance, which is why German companies are more nationally or regionally oriented. In this case, their corporate social responsibility efforts can be oriented more towards national or regional initiatives which are not covered by the corporate social responsibility index. In addition, there are language barriers as it is known that in German-speaking countries English speaking skills are not at high level. Furthermore, national, social, political, and economic institutions play a significant role in shaping practice and performance.

The term "reporting" in terms of corporate sustainability reporting in the Czech Republic appeared after 1990, when the relevant statistical reports on the operations of organizations and mandatory financial statements of companies contained information related to environmental protection, accounting, statistics, social care legislation, etc. (Hřebíček et al., 2012). Reports on corporate sustainability include information on the impact of companies on the environment, financial information, and partly impact on society and this information is legally binding in the Czech Republic. Evaluation of the economic performance of companies in the Czech Republic relies on liquidity indicators, profitability indicators, debt indicators, indicators of financial structure and asset structure, activity indicators, and other indicators (benchmarking, economic value added - EVA, balanced scorecard, etc.). In the Czech Republic, the disclosure of voluntary reports is often adapted to the demands of target groups, in accordance with international standards, such as the Global Reporting Initiative (GRI).

The system of financial reporting in the Republic of Serbia is not perfect. Due to the inconsistent financial reporting in the Republic of Serbia (given frequent changes of regulations), accompanied by incomparable valuation methods of accounting categories, one could say that financial statements, in the best sense, represent only approximation of economic reality. When applying financial criteria in evaluating the efficiency of company operations, it should be borne in mind that the uniform accounting techniques are not used in the successive periods, that balance sheet represents only a snapshot in time (ad diem dictum), that changes in the value of money can have a significant impact on the financial statement values, and that the past cannot constitute a reliable basis for predicting the financial position and result of the company. It is, therefore, essential that the evaluation of performance, in addition to financial indicators, relies on non-financial indicators.

On the territory of the Republic of Serbia, there has been no extensive empirical research on measurement and evaluation of company performance (Domanović, 2010, 2013; Todorović et al., 2015). Research results indicate that companies in the Republic of Serbia predominantly use the metrics of discounted cash flow in investment decisionmaking, while the index of profitability and return period are used to the largest extent, and internal rate of return is applied to a greater extent than the net present value (Todorović et al., 2015). A large number of companies in the Republic of Serbia use solely accounting, although different criteria for evaluating the company performance identified on the basis of information in the financial statements. In this context, the 
emphasis is on profit, contribution margin, return on investment, and earnings before interest and taxes (EBIT), earnings before interest, taxes, depreciation, and amortization (EBITDA), realization and average salary per employee in Euros. Accounting profit and accounting rates of return are still dominant in relation to the modern measures (Todorović et al., 2015). Managers of companies in the Republic of Serbia, in general, do not apply modern integrated models for evaluating the performance of companies for a variety of reasons: lack of information, knowledge, lack of understanding, lack of financial resources for the introduction and implementation of the model, unwillingness regarding change and management innovation, etc. (Domanović, 2010, 2013).

Republic of Serbia has made big step forward by adopting and continuous upgrading of the National Sustainable Development Strategy, which defines sustainable development as target-oriented, long-term, overall, and synergetic process with effects on all aspects of life (economic, social, environmental, and institutional) at all levels. The objective of this Strategy is to establish the balance among the three pillars of sustainable development: sustainable economic growth and economic and technological progress, sustainable social development. Thus, the Strategy makes a significant contribution to overcoming possible conflicting objectives of different aspects of social-economic development, eliminating the gap between the processes of establishing sectoral policies, and establishing a system of mutual advantages. This has been achieved in the joint work on the development of the Strategy through a broad participation of all key stakeholders in the Republic of Serbia.

\section{Conclusion}

The given considerations have confirmed the significance of the simultaneous use of financial and non-financial performance indicators for the purposes of evaluating sustainability. Unlike companies in the European Union, a large number of companies in the Republic of Serbia use solely financial, although different criteria for evaluating efficiency. Only a few companies, dominated by foreign capital, use an integrated system for evaluating performance, designed for the needs of foreign companies, and, as such, transposed into the Republic of Serbia.

Evaluating the performance of companies in the Republic of Serbia predominantly relies on accounting profit and accounting rates of return. Of primary importance are profit, contribution margin, return on investment, EBIT, EBITDA, realization and average salary per employee expressed in Euros.

Previous research has confirmed the hypothesis determined in the introduction. Specifically, companies in the European Union use a wide range of different models for the evaluation of performance, which incorporate financial and non-financial information. In contrast, modest empirical research in the Republic of Serbia has shown that companies in the Republic of Serbia base performance evaluation primarily on traditional financial metrics.

Republic of Serbia has adopted and continually improves the National Sustainable Development Strategy, which accentuates the importance of simultaneous use of financial and non-financial performance indicators. In that way, the Strategy makes a significant contribution to sustainable development in the Republic of Serbia. A large number of 
Serbian companies and banks have started to publish the sustainability reports based on experience of foreign entities that operate in Serbia.

\section{References}

Bini, L., \& Danielli, F. (2011). The Informational Capacity of Financial Performance Indicators in European Annual Reports. Maggioli S.p.A.

Chen, J., Tsou, H., \& Huang, Y. (2009). Service delivery innovation: ancetedents and impact on firm performance. Journal of Service Research, 12(1), 36-55.

Cotter, D. (2012). Advanced Financial Rreporting. Pearson Education Limited: England.

Davies, T., \& Pain, B. (2002). Business Accounting and Finance. McGraw-Hill Education Europe: England.

Davis, S., \& Albright, T. (2004). An investigation of the effect of balanced scorecard implementation on financial performance. Management Accounting Research, $15(2), 135-153$.

Domanović, V. (2010). Balanced Scorecard-mogućnosti i efekti primene. Ekonomski fakultet Kragujevac, Kragujevac.

Domanović, V. (2013). Efektivnost sistema merenja performansi u uslovima savremenog poslovnog okruženja. Ekonomski horizonti, 15(1), 31-44.

Doupnik, T., \& Perera H. (2007). International Accounting. McGraw-Hill: UK.

Fraser, L. M., \& Ormiston, A. (2013). Understanding Financial Statements. Pearson Education International: New Jersey.

Gjølberg, M. (2008). Measuring the immeasurable? Constructing an index of CSR practices and CSR performance in 20 countries. Scandinavian Journal of Management, 25, 10-22.

Grant, R. M. (2002). Contemporary Strategy Analysis: Concepts, Techniques, Applications. Oxford: Blackwell.

Hřebíček, J., Štencl, M., Trenz, O. \& Soukopová, J. (2012). Current trends in corporate performance evaluation and reporting in the Czech Republic. International Journal of Energy and Environment, 1(6), 39-48. http://www.telekomunikacije. rs/upload/images/radovi/broj10rad1files.

Ittner, C. D., Larcker, D. F., \& Meyer, M. W. (2003). Subjectivity and the weighting of performance measures: evidence from a balanced scorecard. The Accounting Review, 78 (3), 725-758.

Jensen, M. C. (2001). Value maximization, stakeholder theory, and the corporate objective function. Journal of Applied Corporate Finance, 14(3), 8-21.

Kotane, I., \& Kuzmina-Merlino, I. (2012). Assessment of financial indicators for evaluation of business performance. European Integration Studies, 6, 216-224

Kothari, J., \& Barone, E. (2006). Financial Accounting: An International Approach. Prentice Hall: Harlow. 
Krstić, B., (2012) Uloga strategijske kontrole u unapređenju poslovnih performansi. Ekonomski fakultet: Niš

Krstić, B., Stojanović, M., Stanišić, T., (2012). Sustainability reporting in order to improve companies' socially recponsible practices, НАУКАБИЗНЕС-ОБРАЗОВАНИЕ: ПРОБЛЕМЫ И ПЕРСПЕКТИВЫ КОМПЕТЕНТНОСТНОГО ВЗАИМОДЕЙСТВИЯ, УЛЬЯНОВСКИЙ ГОСУДАРСТВЕННЫЙ УНИВЕРСИТЕТ - ИНСТИТУТ ЭКОНОМИКИ И БИЗНЕСА, Ульяновск, Редактор: Татьяна Иванова, 156-159.

Krstić, B., \& Sekulić, V. (2013). Upravljanje performansama preduzeća. Ekonomski fakultet: Niš

Krstić, B., Domazet., S. \& Stojanović., M., (2013). Izveštavanje o ekološkim aspektima poslovanja preduzeća kao deo izveštavanja o održivom razvoju, Ecologica (ISSN 0354-3285), No. 71, 387-391.

Krstić, B., \& Bonić, Lj. (2013). Upravljanje vrednošću za vlasnike. Ekonomski fakultet: Niš

Krstić, B., Ivanović, V., (2014). How to apply the Sustainability Balanced Scorecard concept, Economic Themes, 52 (1), 65-80.

Perrini, F., \& Tencati, A. (2006). Sustainability and stakeholder management: the need for new corporate performance evaluation and reporting systems. Business Strategy and the Environment, 15, 296-308.

Peterson-Drake, P., \& Fabozzi, J. F. (2012). Analysis of Financial Statements. Third edition; John Willy \& Sons, Inc.: USA.

Todorović, M., Kaličanin, Đ., \& Nojković, A. (2015). Prakse merenja performansi u preduzećima u Republici Srbiji. Ekonomski horizonti, 17(1), 45-59.

White, G., Sondhi, A., \& Fried, D. (1993). The Analysis and Use of Financial Statements. John Willy \& Sons, Inc.: USA. 